\title{
THE GOVERNANCE OF THE CENTER-Right COALITION
}

\author{
Mark Donovan
}

\section{Public Expectations and Growing Tensions}

The unprecedented government majority that resulted from the 2001 election and the radical promises of the prime minister candidate Silvio Berlusconi had suggested that epochal change could follow the alternation of government from left to right. ${ }^{1}$ Major constitutional and socio-economic reform had been promised that would create a new, successful, and dynamic country of which Italians could be proud. More specifically, the public had been led to believe that the government would enact strong federal reform while reinforcing the executive, perhaps especially the prime minister, and introducing a new era of markedly liberal economic policies. Thus, tax cuts and the promotion of economic growth would create jobs and guarantee continuing high standards of living. The government's "honeymoon period," however, was short-lived. By the end of the year, trust in the government had fallen to just below 50 percent, where it stabilized throughout $2002 .^{2}$ Doubts about the government's ability to deliver reflected its poor performance on economic and social matters, resulting from both the international economic downturn and its own mismanagement of the domestic agenda, most notably industrial relations. ${ }^{3}$ By the autumn of 2003, the Bank of Italy was drawing attention to a two-year period of domestic stagnation and a decade-long investment slump. Government infighting was itself now seen as a cause of government inaction, 
and opinion polls showed that public disillusion was beginning to have a political impact. Thus, while at the end of 2002 voting intentions suggested that the public was still prepared to "wait and see," from the summer of 2003 declared support for the left overtook that for the right. ${ }^{4}$

Conflict within the government had been manifest since January 2002, when Foreign Minister Renato Ruggiero resigned. A former director of the World Trade Organization, Ruggiero's appointment had been intended to symbolize the government's pro-European credentials. He had, however, resigned in protest precisely because of the anti-European sentiment expressed by senior government members. By the end of 2002, the prime minister had only fitfully enforced coalition unity; most of the time, a competitive, rather than a prime ministerial, logic prevailed. ${ }^{5}$ This had not meant, however, that Berlusconi's allies were content. In the summer of 2002, the resignation of the interior minister (forced by public opinion on a reluctant prime minister) coupled with Berlusconi's decision to continue to hold provisionally the Foreign Ministry portfolio himself had encouraged calls for a reshuffle. Gianfranco Fini, the leader of the National Alliance (AN), aspired to the Foreign Ministry himself. More generally, Fini and Marco Follini, the leader of the Christian Democrats (UDC), sought to "rebalance" the coalition so that it was less skewed in favor of Forza Italia and the Northern League (LN).

The League, in fact, was over-represented in the cabinet compared with the share of the majority's national vote that it had obtained, while the National Alliance and the UDC were under-represented. Thus, the League's three ministers represented 12 percent of the total, while it had obtained only 8 percent of the majority's vote (see table 3.1); using the same logic, the UDC and AN could expect an additional seat each. Moreover, the League's three offices were all high profile ones. Its leader, Umberto Bossi, was minister for institutional reform and devolution, and although without portfolio, this office confirmed Bossi's decisive role in promoting the government's federal reform agenda. Second, Roberto Castelli was minister of justice, a key position given the semi-permanent conflict between the prime minister and parts, at least, of the judiciary, and the government's declared intention to overhaul the judicial system. The allocation of this sensitive portfolio to a party other than Forza Italia also helped Berlusconi avoid too manifest a conflict of interest and for some observers implied an exchange logic between the two parties: Berlusconi would ensure federal reform, while Castelli would watch over the prime minister's interests. Thirdly, Roberto Maroni was minister for labor, welfare, and social policy, making him the government's principal 
TABLE 3.1 Coalition parties' share of cabinet seats and alliance vote

\begin{tabular}{lrrrrrrr}
\hline Party & $\begin{array}{c}\text { Proportional vote for } \\
\text { the Chamber in 2001 }\end{array}$ & \multicolumn{2}{c}{$\begin{array}{c}\text { Vote as a proportion of } \\
\text { the majority vote }\end{array}$} & \multicolumn{3}{c}{$\begin{array}{c}\text { Number of } \\
\text { ministers }\end{array}$} \\
\hline & Excl. DE & Incl. DE & Excl. DE & Incl. DE & $\begin{array}{c}\text { Held in } \\
2003\end{array}$ & $\begin{array}{c}\text { Propor. of } \\
\text { min. excl. } \\
\text { DE }\end{array}$ & $\begin{array}{c}\text { Propor. of } \\
\text { min. incl. } \\
\text { DE }\end{array}$ \\
\hline FI & 29.4 & 29.4 & 60.6 & 57.8 & 11 & 15 & 14 \\
AN & 12.0 & 12.0 & 24.7 & 23.6 & 5 & 6 & 6 \\
LN & 3.9 & 3.9 & 8.0 & 7.7 & 3 & 2 & 2 \\
UDC* & 3.2 & 5.6 & 6.6 & 11.0 & 2 & 2 & 3 \\
Independents & & & & & 4 & 0 & 0 \\
\hline Total & 48.5 & 50.9 & 100.0 & 100.0 & 25 & 25 & 25
\end{tabular}

* Democrazia Europea (DE), a third Christian Democratic formation, ran autonomously from the Casa delle Libertà and the Ulivo in the 2001 elections. It subsequently joined with the CCD (Centro Cristiano Democratico) and the CDU (Cristiani Democratici Uniti) and became part of the UDC (Unione dei Democratici Cristiani e Democratici di Centro).

interlocutor with the trade unions in two key policy domains: the labor market and pensions (see table 3.1).

The National Alliance held five posts to the League's three (rather than six to two), and Fini's role as deputy prime minister gave him visibility but little power. Minister for Communications Maurizio Gasparri was both publicly prominent and central to Berlusconi's concerns, given his responsibility for media reform and hence Berlusconi's conflict of interest rooted in the most significant of his "extra-institutional" powers, that is, his influence over the three major private television networks as well as public radio and television. ${ }^{6}$ Nevertheless, Gasparri's authorship of the media regulation bill passed in December was queried by critics (as was Maroni's mastery of his ministry). ${ }^{7}$ The other three AN ministers, Giovanni Alemanno at Agriculture and Forestries, Altero Matteoli at the Environment, and especially Mirko Tremaglia, responsible without portfolio for Italians Overseas, were relatively minor figures, as can be seen from table 3.2. The UDC, as the Christian Democrats became in January 2003, had just two posts, both without portfolio: EU Legislation, held by Rocco Buttiglione, the leader of the former CDU, and Parliamentary Liaison held by Carlo Giovanardi. The CCD leader, Pierferdinando Casini, a loyal ally of Berlusconi since 1994, had become president (speaker) of the Chamber of Deputies. For its part, Forza Italia held nine posts, plus the premiership, and was clearly the senior party in the coalition. It held the major "state" offices of the interior, defense, and, from 2002, 
TABLE 3.2 Berlusconi II cabinet

\begin{tabular}{|c|c|c|}
\hline Prime Minister & Silvio Berlusconi* & FI \\
\hline Deputy Prime Minister & Gianfranco Fini* & AN \\
\hline Foreign Affairs & Franco Frattini & FI \\
\hline Interior & Giuseppe Pisanu & FI \\
\hline Justice & Roberto Castelli & $\mathrm{LN}$ \\
\hline Economy and Finance & Giulio Tremonti & FI \\
\hline Defense & Antonio Martino & FI \\
\hline Education and Research & Letizia Moratti & Non-party \\
\hline Labor, Welfare, and Social Policy & Roberto Maroni & $\mathrm{LN}$ \\
\hline Agriculture and Forestries & Giovanni Alemanno & AN \\
\hline Infrastructure and Transport & Pietro Lunardi & Non-party \\
\hline Communications & Maurizio Gasparri & $\mathrm{AN}$ \\
\hline Production & Antonio Marzano & FI \\
\hline Health & Gerolamo Sirchia & Non-party \\
\hline Culture & Giuliano Urbani & FI \\
\hline Environment & Altero Matteoli & AN \\
\hline \multicolumn{3}{|l|}{ Ministers without Portfolio } \\
\hline Institutional Reform and Devolution ${ }^{\dagger}$ & Umberto Bossi* & $\mathrm{LN}$ \\
\hline Public Administration & Vacant & \\
\hline Parliamentary Liaison & Carlo Giovanardi & $\mathrm{CCD}$ \\
\hline EU Policies & Rocco Buttiglione* & $\mathrm{CDU}$ \\
\hline Regional Affairs & Enrico La Loggia & FI \\
\hline Innovation and Technology ${ }^{\dagger}$ & Lucio Stanca & Non-party \\
\hline Equal Opportunities & Stefania Prestagiacomo & FI \\
\hline Program Implementation & Claudio Scajola & FI \\
\hline Italians Overseas $^{\dagger}$ & Mirko Tremaglia & AN \\
\hline
\end{tabular}

*Party leaders

${ }^{\dagger}$ Ad hoc posts

Notes: The ministerial offices are listed in order of importance as per Verzichelli and Cotta, as derived from Laver and Hunt, adjusting for the new ministerial structures introduced in 2001. The non-portfolio list also follows Verzichelli and Cotta, but three are relatively ad hoc posts. At formation, the government also included 7 deputy ministers and 53 undersecretaries.

Sources: L.Verzichelli and M. Cotta, “Italy: From 'Constrained' Coalitions to Alternating Governments?" in Coalition Governments in Western Europe, ed. W. Müller and K. Strøm (Oxford: Oxford University Press, 2000), 433-497; M. Laver and B. W. Hunt, Policy and Party Competition (New York: Routledge, 1992).

foreign affairs, while the Economics Ministry under Giulio Tremonti was hugely powerful, given its role in allocating resources to the other ministries. The appointment of Forza Italia's Franco Frattini as foreign minister in November 2002 confirmed the party's dominance. Previously, Frattini had been minister without portfolio for public affairs.

During 2003, it became ever more clear that Berlusconi's close relationship with Bossi, and the role of the economics minister in binding Forza Italia and the League together, was the major issue 
affecting the management of the coalition. Indeed, while Tremonti kept Bossi and Berlusconi informed as he developed his budget plans, he kept the junior governmental representatives of the AN and the UDC within his ministry uninformed, contrary to the presumption that "divided portfolios" tend to promote coalition collegiality, limiting ministerial autonomy. ${ }^{8}$ Emblematic of the importance of the Berlusconi-Tremonti-Bossi axis, which reversed the prime minister's relative neglect of the League in his 1994 government, was the troika's meeting for dinner every Monday evening at Berlusconi's palatial home in Arcore. However, by excluding the leaders of two of the four parties composing the coalition, this arrangement was dysfunctional to coalition management, provoking a process of polarization within the government. Thus, by November, Follini and Fini were said to be co-ordinating on a daily basis their tactics to force a renegotiation of the coalition agreement regarding both policy priorities and portfolio assignment. ${ }^{9}$

\section{The Run-Up to the May-June Elections}

In January 2003, the government formally launched a project of constitutional reform in accord with its campaign program. Particularly significantly for this chapter, Berlusconi presented the "year of the great reforms" as including the reinforcement of the head of the executive, enabling him "to hold his majority in the palm of his hand" (tenere in pugno anche la sua maggioranza). The statement appears to confirm Berlusconi's alleged frustration with the difficulties of unifying his majority behind its program. While the project made headlines for a brief period, and had the backing of both the president of the Republic and the presidents of both parliamentary Chambers, albeit on the understanding that the process would embrace the opposition, it faded into the background thereafter, excepting that its fitful progress was periodically linked to conflict within the coalition itself. In fact, a major constitutional split divided the coalition, with the National Alliance and the UDC concerned to preserve the integrity of the Italian state and its central institutions, which they saw as threatened by the Northern League's radical proposals.

In April, continuing immobilism over state reform, resulting from mutual veto within the coalition, forced the government to move the center-left's incomplete project forward in order to avoid administrative chaos. This infuriated Bossi, who forced a second reading of his devolution bill by threatening otherwise to bring the government down. As a constitutional reform, the bill required two further readings 
after at least six months had passed and was thus something of a ticking time bomb. Bossi's bill implied the discontinuation of nationwide standards of service provision in health and education, the establishment of local police forces independent of the central state, and the possibility of growing regional autonomy on an asymmetric basis, thus reinforcing the likelihood that the North-South divide would acquire an institutional dimension. Unable to veto Bossi's ultimatum without itself jeopardizing the government's survival, the UDC, backed by the National Alliance, itself threatened just such a course of action unless a broader "reform of the reform" was also agreed. Bossi's bill was thus paralleled by the passage in cabinet of the so-called La Loggia bill revising the center-left's legislation and, in particular, explicitly endorsing the notion of the "national interest." Although hammered out by a small group that included himself, Bossi vociferously and accurately denounced the bill as a "centralizing counter-reform." 10 The confused, "triple track" nature of the government's approach to reforming the structure of the state in this period illustrates the impact of coalition disagreement on Italian constitutional development.

In the meantime, conflict over other issues had been more publicly prominent (see table 3.3). Probably most visible among these were disputes over candidate selection for the forthcoming local elections, including the regional election in Friuli-Venezia Giulia. Before discussing the election issues, however, the several other issues dividing the coalition will be briefly outlined.

- Leniency toward prisoners: In a historic first address by a pope to the Italian Parliament, John Paul II had appealed in 2002 for leniency toward Italy's convicts. The suggestion was embarrassing, since it challenged the state's lay identity, yet to ignore it would be undiplomatic. Looking on it as a means to alleviate prison overcrowding, and the UDC and Forza Italia proposed a bill, which the League and the Northern Alliance opposed. In a tormented passage back and forth between the two Chambers over several months, the bill was repeatedly revised in a less liberal direction by the latter parties, and rerevised by the former parties, with the support of the opposition.

- Parliamentary immunity and judicial reform: This issue was particularly pressing, given that the prime minister faced possible conviction for fraud and the corrupting of judges in the socalled Imi-Sir and SME trials. League backing for proposals on parliamentary immunity contrasted AN and UDC concerns, which in part reflected the hostility of public opinion: 70 percent 
TABLE 3.3 Issues dividing the majority

\begin{tabular}{|c|c|}
\hline Month & Issue \\
\hline January & $\begin{array}{l}\text { Candidate selection, Friuli-Venezi Giulia regional election } \\
\text { Clemency bill } \\
\text { Parliamentary immunity }\end{array}$ \\
\hline February & $\begin{array}{l}\text { Judicial reform } \\
\text { Candidate selection, extending to local authorities } \\
\text { EU milk quotas }\end{array}$ \\
\hline February-March & RAI Management Board \\
\hline March & Parliamentary immunity \\
\hline March-May & Local election campaigns \\
\hline April & $\begin{array}{l}\text { State reform, especially "devolution" } \\
\text { Clemency bill } \\
\text { European arrest warrant-LN opposition }\end{array}$ \\
\hline May & $\begin{array}{l}\text { Milk quotas } \\
\text { Parliamentary immunity } \\
\text { First-round local election results }\end{array}$ \\
\hline June & $\begin{array}{l}\text { Pension reform } \\
\text { Second-round local election losses } \\
\text { Concentration of power in Economics Ministry (Tremonti) } \\
\text { Immigration }\end{array}$ \\
\hline June-July & Clemency \\
\hline July & $\begin{array}{l}\text { Fini's role as deputy prime minister } \\
\text { Concertation with trade unions } \\
\text { Sofri clemency }\end{array}$ \\
\hline August & $\begin{array}{l}\text { Savings bank } \\
\text { Proposed parliamentary inquiry into alleged judicial } \\
\text { subversion } \\
\text { Ministry of Defense property sales } \\
\text { Football leagues' crisis }\end{array}$ \\
\hline August-October & Pension reform \\
\hline September & $\begin{array}{l}\text { Berlusconi's Spectator interview } \\
\text { Budget secrecy } \\
\text { Proposed single list for European Parliament election } \\
\text { (June 2004) }\end{array}$ \\
\hline October-December & Immigrant vote proposal \\
\hline October-December & New Year reshuffle \\
\hline October-November & Gasparri bill \\
\hline November & European arrest warrant \\
\hline
\end{tabular}

of the public was against the bill, while 60 percent believed that the prime minister should resign if found guilty. ${ }^{11}$

- Milk quotas: The League championed the interests of milk producers, while the AN minister of agriculture and fisheries sought to "re-establish legality," prioritizing Italy's relationship with the EU. Tremonti's intervention on LN's behalf in Ecofin was robust, while at home the prime minister backed his economic minister's decisive actions. 
- RAI: The resignation of three of the five members of the RAI management board left the League's nominee and the chair in post, a situation ruled to be legal but of questionable legitimacy. The National Alliance took the lead in forcing their resignation via a parliamentary maneuver, to the fury of the League, which had sought to exploit its position to shift production of RAI 2 to Milan.

The selection of candidates for the May-June elections took place throughout the early months of the year and was particularly marked by Bossi's brazen pursuit of his party's interests, rather than those of the coalition. On 17 February, the League's federal council issued a "programmatic decalogue" specifying what it required of its allies in order not to stand League candidates in competition with the Polo, i.e., the candidate of the other three center-right parties. The demands included the passage of a decree introducing fiscal federalism, definitive agreement on the devolution bill, resolution of the milk quota issue, and federalization of the RAI. ${ }^{12}$ Agreement a week later on an independent candidate for the Friuli-Venezia Giulia regional election did not last, while Berlusconi's agreement to the candidature of the League's Alessandra Guerra, in early March, caused his regional party organization, backed by the national party co-ordinator, Roberto Antonione, himself a Friulian, to revolt. This center-periphery conflict within Forza Italia, coming on top of other, more minor ones, had consequences not only for Forza Italia. The resignation of Antonione and several leading local organizers contributed to the right losing the Udine election as well as the regional one, and subsequently Berlusconi sought to reduce the power of his party's organizational machine. Thus, Antonione was not replaced by Claudio Scajola, the man who had built the party's new mass membership organization after 1997, even though his earlier resignation as interior minister made him available. Scajola's success in building a party rooted at ground level was now seen as having reinforced the organization's bureaucratic self-interest, rendering it inflexible as a tool to help manage the coalition. Events in Friuli in the first half of 2003 thus encouraged Berlusconi to reaffirm his role as the leader of a multi-party alliance, first, and of Forza Italia only second. Consequently, Forza Italia's generally weak territorial rootedness is likely to continue. ${ }^{13}$ Whether this will in fact assist coalition cohesion remains to be seen. The decline in declared voting intentions for the alliance parties since the summer of 2003 has concentrated on Forza Italia, rather than its allies, ${ }^{14}$ and this may encourage the other parties to expect to benefit from a "post-Berlusconi" political scenario. 
Bossi's electoral intransigence was evidenced beyond Friuli. A subsequent agreement that he would run independently in local elections only in Brescia was also not maintained, leading to "candidate chaos" in the Veneto as well as in Friuli. ${ }^{15}$ In any event, the League ran against the Polo in 21 authorities in Lombardy and the Veneto, while in Treviso a three-way split saw the UDC also stand independently of Forza Italia and the National Alliance. ${ }^{16}$ Elsewhere, too, the right was divided; for example, AN and FI competed against each other in Trapani (Sicily), while in Rome AN accused its allies, especially Forza Italia, of failing to support its provincial presidential candidate. The defeat of the Rome candidate at the first ballot on 25-26 May was particularly galling to AN, given the city's symbolic significance and AN's hope of building on success to capture the regional authority in 2005. Despite defeat in Rome, the first-round results were not especially bad for the government. However, the success of the UDC, which obtained 12 percent of the vote nationwide and 18 percent in Sicily, boosted that party's determination to make its weight felt within the coalition. The full election results were known only after the second round, and the Friuli regional vote, held on 8-9 June.

\section{The Election Results and Their Consequences}

The June results saw the right lose control of Friuli-Venezia Giulia and of several local authorities. The losses were limited with regard to the 12 provinces and 9 provincial capitals contested, the number controlled by the right and the left shifting respectively from $6: 6$ to $5: 7$, and from 5:4 to 4:5. However, even if there was no uniform swing against the government (see Legnante in this volume), the situation was not good for the right, looking at the generality of the larger towns and cities where the left-right ratio changed sharply from 41:39 to 50:30. ${ }^{17}$ Mutual recrimination rang loud as the AN, the UDC, and the League blamed each other for the setback. Unwilling to accept the blame, and seeking to channel rank-and-file dissent, Bossi summoned his party's federal council and attacked the League's allies as Romanophile enemies of the North. More specifically, he demanded a precisely dated timetable for legislating the government's constitutional reform program. The National Alliance demanded a majority summit focusing on issues central to its electorate: public sector employment, public works investment, armed forces pay, welfare and institutional reform, that is, a strengthened core executive, while seeking also to boost the role of the deputy prime minister with regard to economic co-ordination. Without this last item in particular, 
it was suggested that Fini might leave the cabinet to tend his party. For its part, the UDC called for the funding of the schools' reform, especially with regard to private (i.e., Catholic) schools, more attention toward families, southern investment, and research to boost economic competitiveness. ${ }^{18}$ These reactions suggest that the unpublished coalition agreement underlying the formation of the House of Freedoms in 2000 was imprecise and even contentious. Indeed, both AN and the UDC wanted to revise the government's program and the cabinet's composition via a majority summit.

The last thing Berlusconi wanted was to renegotiate the basics of the coalition's existence. He responded by signaling his "incredulity" at his allies' indiscipline, warning that if the government fell, the president might appoint a non-party prime minister rather than calling elections. And a second collapse of a center-right government after that of 1994, resulting in a government led by a technocrat, would suggest that the right was inherently unable to govern. ${ }^{19}$ Rather than call a coalition summit, Berlusconi consulted the party leaders individually, letting it be known that Tremonti was at work identifying what funds were available to try to satisfy the parties' demands in the forthcoming budget. Continuing economic stagnation, however, left the government with little to distribute. Berlusconi thus sought to persuade the League, the main opponent of pension reform, of the necessity of that measure, while refocusing the coalition's attention on constitutional reform, offering each party what it most wanted: federalism for the League, a reinforced executive for the National Alliance, and a return to proportional representation for the UDC. All this was to be wrapped up in a document relaunching the government's program. This narrowly focused document, however, glossed over the tensions in the constitutional reform program and ignored the key issue of access to resources pursued by the AN and the UDC, which wanted to break Tremonti's stranglehold on the government's purse strings.

To regain the political initiative, Bossi launched one of his periodic bursts of firework diplomacy. Over a period of several days, he attacked the continuing spectacle of seaborne refugees seeking illegal entry to Italy and the failure to release the funding needed to implement the new immigration law designed by himself and Fini. His call on the interior minister to authorize the navy to shell illegal immigrant boats caused particular clamor. ${ }^{20}$ Bossi's tactical success infuriated Fini, who continued to insist on the need to "rebalance" the coalition, perhaps by reinstituting a "directory," that is, an inner cabinet of the party leaders. Berlusconi rejected this idea on the grounds that the UDC leader was not a member of the cabinet. ${ }^{21}$ And Bossi 
continued to threaten the coalition's survival if his demands were not met, describing the League to his followers as standing with "both feet outside government, but its fist inside" (La Lega sta con due piedi fuori dal Palazzo e un pugno dentro).22

By late June, speculation about a possible government crisis was tempered by the knowledge that this was unlikely to happen while Italy held the EU Council presidency. Nevertheless, negotiations between the parties continued, and immediately after Berlusconi's internationally reported gaffe in the European Parliament, which visibly caused his deputy grave embarrassment, ${ }^{23}$ the prime minister conceded an enhanced role to Fini, establishing a Co-ordination Office (Cabina di regia) for social and economic affairs within the cabinet. This was not to be, however. Bossi sabotaged the new institution by voting against four government measures the day before its first scheduled meeting, which, furthermore, he made obvious he would not attend. Rumors that the UDEUR might replace the League as a coalition partner may have constituted an attempt to pressure Bossi, and certainly Fini broke a taboo by publicly stating, after the failure of the Co-ordination Office initiative, that the League was not indispensable. This view was immediately squashed by Forza Italia, however, as implying an inconceivable return to transformism (that is, opposition MPs transforming themselves into government supporters). More prosaically, the UDEUR had only $17 \mathrm{MPs}$, compared to the League's 46, and could provide the government with only a wafer-thin majority in the Senate (see table 3.4).

Pension reform had meanwhile become a major issue within the coalition following Berlusconi's statement in favor of it at the G8

TABLE 3.4 The parliamentary majority

\begin{tabular}{lccc}
\hline Group & $\begin{array}{c}\text { Size } \\
\text { Chamber, } \\
\text { April 2001 }\end{array}$ & $\begin{array}{c}\text { Chamber, } \\
\text { October 2003 }\end{array}$ & $\begin{array}{c}\text { Senate, } \\
\text { November 2003 }\end{array}$ \\
\hline Forza Italia & 178 & 176 & 80 \\
National Alliance & 99 & 99 & 47 \\
Lega Nord-Padania & 30 & 29 & 17 \\
UDC & 40 & 38 & 30 \\
Government total & 347 & 341 & 174 \\
Total for Chamber & $619^{*}$ & 617 & 321 \\
Majority & 310 & 309 & 161 \\
UDEUR & - & 11 & 4 \\
\hline
\end{tabular}

*Owing to disputes about the application of the electoral rules, 11 seats in the Chamber of Deputies were never filled. Normally, the Chamber comprises 630 deputies, subject to any by-elections pending. 
summit. Since 70 percent of the 3.5 million "seniority" pensions are held in northern Italy (38 percent in Lombardy alone), structural pension reform closely affected the League. Consequently, it campaigned instead for action to be taken against the abuse of the invalidity pension, 62 percent of whose 4.3 million recipients are located in southern Italy, thus challenging the interests of the AN and UDC. ${ }^{24}$ This issue returned to the top of the agenda in the autumn, as discussed below. Of less lasting significance, but emblematic of the cultural differences between the government parties, was a brief but intense conflict over the issue of clemency for Adriano Sofri. A left-wing intellectual, Sofri had been found guilty in 1997 of the terrorist murder of a policeman in 1972 on the sole basis of a statement made many years later by a repentant participant who named Sofri as having instigated the assassination. Despite cross-party support for the amnesty, apparently backed by the prime minister and the president of the Republic, Justice Minister Roberto Castelli vetoed the suggestion with an angry polemic against communist terrorism. The League's perceived incivility and excessive influence on the government provoked Forza Italia's regional co-ordinator for the Marches to resign and join the UDEUR, expressing his hope that a "grand center" would be restored, ${ }^{25}$ that is, a centrist or center-right government in which the League would not be represented. Such views were typical of Catholic moderates, and Follini, the UDC leader, apparently told Berlusconi that the disputes within the majority amounted to a "battle of civilization" (uno scontro di civiltà). ${ }^{26}$ Increasingly, the UDC and AN anticipated a future when Berlusconi would no longer dominate the right, allowing it to be reconstructed.

After months of polemic, on 22 July the government voted compactly on two highly controversial measures, the conflict of interest bill and the so-called Gasparri bill regulating the media. These examples of government cohesion on issues closely involving the prime minister's personal interests led to the suggestion that Berlusconi's generally weak leadership was actually gamesmanship. That is, he enforced discipline when it was vital to him, often requiring his allies to accept measures that they and their supporters were unhappy with, yet allowing them to vent their frustrations in areas of less concern to him. ${ }^{27}$ Were this analysis correct, it would suggest that the description of Forza Italia (and by extension of the coalition) as a clan, rather than a broadly liberal-conservative force representing the collective interests of the nation, or at least the center-right, remained substantially accurate 10 years after Berlusconi's entry into politics. ${ }^{28}$

The prime minister's attempt to focus his coalition's attention on constitutional reform led to the formation of a four-man group comprising 
a senior representative from each party to unify the parties' various positions, in part reflecting the demand of AN and the UDC for "equal dignity." On 24 August, this so-called Lorenzago group, named after the holiday resort it stayed in, published a draft document that met widely contrasting views as to its wisdom. Meanwhile, the parties continued to jockey for position. In Sardinia, a protracted crisis of the regional government saw the UDC seeking to wrest the presidency from Forza Italia. At the end of July, even AN was roused to protest the UDC's "politicization" of a "technical" query raised by the justice minister, which briefly blocked judicial investigation into Mediaset (Berlusconi's media holding) dealings in the US. In early August, the UDC delayed approval of the Gasparri bill until after the summer break. In late August, the National Alliance pushed for the government to intervene in a football league crisis that threatened to jeopardize the start of the season, and Berlusconi did so, despite Bossi's protests. The description of this success for AN as a scrap thrown to a faithful dog by its master reflected commentators' views of AN's abject subordination within the coalition. ${ }^{29}$ Sniping also began in this period over the decision by Berlusconi and Tremonti to include in the budget an amnesty for building constructions erected without a license. While the AN was highly critical, the League was supportive, maintaining the driving force of the coalition's core troika. By September, the air of crisis had returned. The UDC stated that it regarded the remaining trimester as "an armed truce," preceding the settlement of outstanding business in the new year. It also suggested that it might withdraw from the government (if not the majority) if its concerns were not met. ${ }^{30}$ By the end of the month, Fini's party was described as being in revolt. ${ }^{31}$

\section{Fini’s Autumn Offensive}

On 16 September, the government unveiled its constitutional reform project. Two days later, it was announced than an accord had been reached on pension reform and the budget, including the amnesty for building constructions. Berlusconi had met Bossi's demands, in particular, to take personal responsibility for pension reform, not least via a nationwide television broadcast on 30 September in which he explained the government's imperative need to be able to raise funds in a situation of European economic downturn. The left-liberal newspaper La Repubblica claimed that UDC approval had been gained by massive funding of private (i.e., Catholic) schools. Subsequently, it was reported that UDC opposition to the Gasparri bill was bought off 
by increasing the party's influence over the regional news media and on the enlarged RAI management board. ${ }^{32}$ What the National Alliance gained was less clear, and the budget continued to be assailed by amendments, not least from within the majority. Joint AN-UDC pressure did decouple the government's presentation of the budget on 29 September from its presentation of the pension reform on 3 October, nominally to give another chance for consultation with the unions. Both AN and the UDC feared that the stance adopted by the Catholic union, the CISL, toward the government could be decisive for the next election. But this was too little too late. The unions called for a general strike on 24 October and mass demonstrations on 6 December.

In late September, government MPs voted against the Gasparri bill under cover of the frequent application of the secret vote (so-called sniper fire), and on 2 October an opposition amendment was approved, forcing the bill's return to the Senate. The National Alliance was regarded as the main culprit, two of the main internal factions having just denounced the party's weakness and loss of identity. On 4 October, the cabinet nevertheless approved the pension reform, forcing public and international perception of the government to change: this was a significant structural reform. While this boost to the government's credibility was being digested, Fini launched a proposal that re-established his party's agenda-setting role: the granting of the vote to immigrants in local elections. This was a masterstroke. A large majority of Italian opinion had favored such a development since at least $1999,{ }^{33}$ even including threefourths of AN voters. ${ }^{34}$ Fini was seeking to quell the lingering perception that the AN was an extreme right-wing party and to saddle that label uniquely and decisively on Bossi's League, and perhaps even to force Bossi to leave the government in protest, since Fini made it clear that he would not renounce the proposal on the grounds that since it was not in the government program, and Parliament was sovereign, he could promote it independently. The UDC was strongly supportive, while Berlusconi was forced to align with Fini, given the overwhelming support for his proposal. The League was isolated. Bossi briefly threatened his personal withdrawal from the government, but under pressure from Berlusconi reversed his position to one whereby Padania's enemies would be unable to force him to abandon the struggle for devolution. The AN's revived protagonism was also linked to a rumor that the AN and UDC had agreed to co-ordinate their campaigns for a government reshuffle in January. ${ }^{35}$ On 10 October, Berlusconi conceded that a reshuffle would take place, perhaps replacing the non-party ministers, with the exclusion of Moratti in Education, where major and popular reforms were 
already underway. On 24 October, Berlusconi sought to reassert his authority over his cabinet, blaming his allies for the government's declining poll ratings. His main concern seemed to be to establish that the Economics Ministry, Fini and Follini's key objective, was inviolable, and that no formal government crisis would be allowed, only a reshuffle. Berlusconi wanted to head the longest surviving government in the history of the Republic, and to campaign for the next election as the prime minister of a government that had survived an entire Parliament-and had been effective, too.

In November-December, Fini confirmed his party's agenda-setting role during and following a long sought-after official visit to Israel. A number of statements, such as Fini's declaration that fascism (or perhaps only its collaboration in the Holocaust) had been an "absolute evil," appeared definitively to establish his party's anti-fascist credentials so as to make him a credible future leader for the Italian right. For anti-Berlusconi optimists, the implication was that Fini was anticipating the possibility that the right could lose the 2006 election, forcing Berlusconi to stand aside and thus enabling the right to be reconstructed on a less divergent basis. ${ }^{36}$ While the four government parties had a competitive relationship, as demonstrated by Berlusconi's inability to unify them under a single alliance list for the European elections, and it was probably even true that all four were unhappy with the alliance's variegated identity, a more realistic perspective was offered by the UDC leader. For Follini, the nature of the right was anomalous and not what he wanted, but it was unlikely to come to an end in the near future. ${ }^{37}$ Indeed, on 2 December the government majority voted compactly on the crucially important Gasparri law.

As the year drew to an end, the coalition's future remained uncertain, not least because of the prime minister's conflict of interest and delicate judicial position. Thus, on 15 December, the president of the Republic referred the Gasparri bill back to Parliament for further consideration in respect of a series of rulings by the Constitutional Court. The same court was also due to rule on the so-called Maccanico-Schifani law, which would suspend criminal proceedings against the five senior officials of the state while they were in office. A negative verdict on the latter would expose Berlusconi once again to criminal trial proceedings, in which his personal lawyer, Cesare Previti, had just been found guilty of corrupting judges, receiving a sentence of four years on top of the 11 years he had received in April (also for bribing judges). The importance of these decisions was another reason why the coalition summit had been delayed to January. Thus, a government reshuffle seemed certain, but the strength of the various players, and thus the outcome, depended on these constitutional developments as well as, 
perhaps, on whether the state reform bill would obtain its first reading in January, as demanded by Bossi. In any event, a complete return to the system of allocating cabinet seats in proportion to parties' votes that had typified the "First Republic" seemed unlikely, despite the demand of the AN and the UDC for "equal dignity." Taking away a seat from the League was out of the question. It was more likely that an additional portfolio would be created for AN and for the UDC, the latter perhaps for Sergio D'Antoni, the leader of the UDC's third component, Democrazia Europea (DE), currently unrepresented in government. While speculation went beyond these minimalist probabilities, suggesting, for example, that Fini would be allocated the Defense Ministry, the situation was very uncertain, and shifts relating to the non-party ministers would be easier to manage than ones affecting Forza Italia itself.

\section{Conclusion}

Despite the conflict clearly manifest in the House of Freedoms during 2003, there is a view that the alliance is doomed to govern-at least until 2006. This reflects a general consensus that, at the parliamentary level at least, the Italian party system has shifted decisively toward consolidation on a bipolar basis. There is little room for maneuver for the disaffected within the coalition. They can threaten symbolic challenges, such as the withdrawal of the party leader from the cabinet or of the party into external support, maneuvers typical of the "First Republic," it must be said. But veto power-the ability to block other parties' policy preferences-seems to have limits; that is, determined parties can force policy development and can claim that they must to avoid withdrawing from government in order to stem internal party revolt. Equally, the impact on the public of policy immobilism has been disillusionment and the possibility of losing the next elections. Berlusconi and Tremonti seem to have turned this electoral constraint into an opportunity for coalition management, pulling a serious pension reform "out of the hat" in the final quarter of the year. It remains to be seen whether judicial reform and constitutional reform can also be achieved on the same basis. If so, it would suggest that coalition government, rather than merely ministerial government, has prevailed.

The lack of alternatives has, nevertheless, produced a notable schizophrenia in two of Forza Italia's allies especially. The National Alliance and the UDC are reluctant allies of Berlusconi and extremely reluctant allies of Bossi. They have lived though a year in which there 
was a possibility that Berlusconi would be forced to resign as a result of criminal trial proceedings. But this did not happen. For the time being, if the right is to govern, it must govern as it is. The presidential referral of the Gasparri law, like the veto power of the Constitutional Court, suggests that constitutional guarantees might assist this by acting as "escape clauses." Allies unwilling to bring the government down by refusing to back crucial legislation can justify their behavior to their own parties by the need to maintain the coalition and the possibility that the legislation will not be definitively enacted despite the support of the parliamentary majority.

Writing of the development of a bipolar, rather than a one-party, dominant system in Sweden, David Arter described the alliance of the three "bourgeois parties" as a ménage à trois that was "essential to divorcing the social democrats from power." One can say something similar about the alliance of the four parties of Italy's House of Freedoms. The purpose of this ménage à quatre is to keep the left out of power-and themselves both in power and intact. There is every likelihood that defeat in parliamentary elections would be catastrophic for an alliance that is held together by government power and Berlusconi's success as a political leader. In terms of party identities, the coalition is in many respects a negative one, built to deny power to the opposition, similar to the coalitions that arose against the old Christian Democrats (DC). In the so-called Second Republic, this heterogeneous governing coalition could lose the next election, and there are signs that this makes a difference to coalition cohesion and policy output. Still, coalition breakdown should not be considered a given in this scenario. The future is very uncertain.

\section{Notes}

I should like to thank Salvatore Vassallo for his invaluable feedback on the first draft of this essay as well as the editors and the Cattaneo Institute for organizing the workshop in Bologna in November 2003.

1. J. Blondel and P. Segatti, "Introduzione. Il secondo governo di Berlusconi," in Politica in Italia. Edizione 2003, ed. J. Blondel and P. Segatti (Bologna: Il Mulino, 2003), 29-48.

2. P. Natale, "Berlusconi e il consenso infedele," Italianieuropei, no. 4 (2003): 33-46. 
3. Blondel and Segatti, "Introduzione"; A. Accornero and E. Como, "La (mancata) riforma del governo Berlusconi. I primi 18 mesi," in Blondel and Segatti, Politica in Italia, 239-262.

4. R. Mannheimer, "Realistico il 'pareggio' tra i Poli. Dal autunno calo più marcato," Corriere della Sera, 25 October 2003; Natale, "Berlusconi."

5. M. Cotta and L. Verzichelli, "Il governo Berlusconi II alla prova: un anno di complicazioni," in Blondel and Segatti, Politica in Italia, 49-71.

6. M. Salvati, "Quali riforme nell'era del fattore B," Corriere della Sera, 22 September 2003, 1 and 8.

7. Dario del Vico, "Storace a Gasparri la legge non è tua," Corriere della Sera, 28 September 2003, 6. It is said that Maurizio Sacconi, a Forza Italia undersecretary close to Confindustria, the industry association, rather than Maroni dominates government labor policy.

8. W. Müller and K. Strøm, "Coalition Governance in Western Europe: An Introduction," in Coalition Governments in Western Europe, ed. W. Müller and K. Strøm (Oxford: Oxford University Press, 2000), 24; S. Rizzo, "Pensioni, l’idea dei disincentivi. Devolution in cambio alla Lega," Corriere della Sera, 20 June 2003.

9. B. Jerkov, "Fini pronto a giocare col premier la carta dell'opposizione esterno," La Repubblica, 9 November 2003.

10. R. Zuccolini, "Federalism. La Lega contro tutti,” Corriere della Sera, 28 April 2003.

11. F. Bordignon, “Gli italiani bocciano l’immunità,” La Repubblica, 17 May 2003.

12. "Amministrative, le condizioni del Caroccio," Corriere della Sera, 18 February 2003.

13. I. Diamanti, “Le debolezze di Forza Italia," Il Mulino 52, no. 408 (July- August 2003): 629-636.

14. Natale, "Berlusconi," 41-42.

15. P. Di Caro, "Bossi non cede al premier," Corriere della Sera, 28 March 2003; R. Bruno, "Lega da solo in Veneto," Corriere della Sera, 16 April 2003.

16. F. Cavalera, "Bossi: ho vinto la scommessa," Corriere della Sera, 27 May 2003, 8.

17. "Elezioni amministrative, comuni superiori ai 15,000 abitanti (escluso capoluogo)," Corriere della Sera, 10 June 2003.

18. D. Gorodisky, "Basta galleggiare su scuola e famiglia," Corriere della Sera, 12 June 2003.

19. B. Jerkow, "E Berlusconi agita lo spettro del 'governo presidenziale," Corriere della Sera, 5 July 2003.

20. "Lotta ai clandestini, Bossi sotto accusa," Corriere della Sera, 17 June 2003.

21. P. Di Caro, "Berlusconi frena Fini," Corriere della Sera, 28 June 2003.

22. R. Bruno, "Bossi: con due piedi fuori del Palazzo," Corriere della Sera, 29 June 2003.

23. Berlusconi likened the leader of the German Christian Democratic group to a concentration camp tyrant.

24. "Il primato dell'anzianità al nord," Corriere della Sera, 7 July 2003.

25. R. Bruno, “Cambio di coalizione,” Corriere della Sera, 22 July 2003.

26. F. Vederami, "Il Premier: non ho l'acqua all gola. Senza di me si suicidano," Corriere della Sera, 10 July 2003.

27. F. Merlo, "Maggioranza in riga-molti cavalli ma il Cavaliere é uno solo," Corriere della Sera, 24 July 2003.

28. P. McCarthy, The Crisis of the Italian State: From the Origins of the Cold War to the Fall of Berlusconi (Basingstoke: Macmillan, 1995); McCarthy, "Forza Italia: The New Politics and Old Values of a Changing Italy," in The New Italian 
Republic: From the Fall of the Berlin Wall to Berlusconi, ed. S. Gundle and S. Parker (London: Routledge, 1996), 130-146.

29. A. Grasso, "Tanti vincitori, pochi vinti," Corriere della Sera, 20 August 2003.

30. C. Tito, "La tentazione dei centristi: stop alle riforme istituzionali," La Repubblica, 7 September 2003.

31. M. Franco, "Odio per Bossi e autocritic. AN in crisi di identità," Corriere della Sera, 28 September 2003.

32. D. Di Vico, "A Saxa Rubra si dà per certo il sì dei 'centrist,' " Corriere della Sera, 21 September 2003.

33. I. Diamanti, "I fini ambigui del voto agli stranieri," La Repubblica, 11 October 2003.

34. R. Mannheimer, "Il 70\% dice sì alla svolta del vicepremier," Corriere della Sera, 11 October 2003.

35. P. Di Nicola, “E la Lega la pagherà,” L'Espresso, 9 October 2003.

36. M. Donovan, "Berlusconi, Strong Government and the Italian State," Journal of Modern Italian Studies 8, no. 2 (2003): 231-248.

37. M. Franco, "Follini: tormenti del politico 'di mezzo,'” Corriere della Sera, 23 November 2003. 